\title{
Novel Latent Fluorophore for DT Diaphorase
}

\author{
Sheng-Tung Huang ${ }^{*}[a]$ Yuh-Lin Lin ${ }^{[b]}$ \\ ${ }^{[a]}$ College of Engineering, Department of Chemical Engineering and Biotechnology, National Taipei \\ University of Technology, Taipei, 106, Taiwan, R. O. C \\ ${ }^{[b]}$ College of Medicine, Department of Medicine, Fu-Jen Catholic University, Hsin-chuang, Taipei \\ Hsien 24205, Taiwan, R. O. C
}

\section{Supporting Information}

\section{General Experimental}

Proton and carbon NMR were obtained using a Bruker AMX-500 spectrometer. Chemical shifts were reported in ppm relative to tetramethylsilane ( $\delta$ units). Elemental analysis was recorded using a Micromass ZAB spectrometer and Perkin-Elmer 2400 elemental analyzer at the Analytical Facility of The National Taiwan University. The IR spectra were obtained using the Perkin Elmer Spectrum RXI FT-IR system. Pyridine was dried by reflux from $\mathrm{CaH}_{2}$. All other chemicals were purchased from Across, Aldrich or TCI and used without future purification. The enzyme DT Diaphorase human was purchased from Sigma Chemical (St. Louis MO; product number D1315). The glucose dehydrogenase from Bacillus megaterium was purchased from Fluka (product number 49165). All measurements were performed in $100 \mathrm{mM}$ PBS with $1 \mathrm{mM}$ EDTA (pH 7.3). The stock solution of 3 prepared in DMSO and added to PBS before use, and the DMSO concentrations never exceeded $1 \%(\mathrm{v} / \mathrm{v})$ in all the experiments. The fluorometric measurements were made with using a fluorescence grade quartz cuvette, and a Perkin-Elmer LS 50 spectrofluorometer.

\section{Synthesis of 3}

Quinone acid $1(1.88 \mathrm{mmol})$ was dissolved in $10 \mathrm{~mL}$ of a 1:1 mixture of dry pyridine/DMF at room temperature under argon and treated with EDCI $(1.88 \mathrm{mmol})$, and the mixture stirred for $1 \mathrm{~h}$, The resulting solution was added rhodamine 110 (2) $(0.47 \mathrm{mmol})$, and stirred at room temperature for $30 \mathrm{~h}$. After $30 \mathrm{~h}$, the mixture was diluted with $100 \mathrm{~mL}$ of EtOAc, then washed with $100 \mathrm{~mL}$ of water and $100 \mathrm{~mL}$ of 0.2 $\mathrm{N} \mathrm{HCl}$. The organic layer was dried with $\mathrm{MgSO}_{4}$ and concentrated under reduced pressure to provide a crude product. The crude product was purified by silica gel 
chromatography as a light yellow solid ( $38 \%$ yield). Mp: $232-233{ }^{\circ} \mathrm{C} ; \quad \mathrm{IR}(\mathrm{KBr}) v_{\max }$ : $3550,3331,2962,2925,1768,1754,1642,1613 \mathrm{~cm}^{-1} ;{ }^{1} \mathrm{H}$ NMR $\left(500 \mathrm{MHz}, \mathrm{CDCl}_{3}\right) \delta$ $1.48(12 \mathrm{H}, \mathrm{s}), 1.95(6 \mathrm{H}, \mathrm{s}), 1.96(6 \mathrm{H}, \mathrm{s}), 2.15(6 \mathrm{H}, \mathrm{s}), 3.03(4 \mathrm{H}, \mathrm{s}), 6.65(2 \mathrm{H}, \mathrm{d}, J=$ 8.6), $6.91(2 \mathrm{H}, \mathrm{d}, J=8.6 \mathrm{~Hz}), 7.07(1 \mathrm{H}, \mathrm{d}, J=7.3 \mathrm{~Hz}), 7.38(2 \mathrm{H}, \mathrm{s}), 7.55(2 \mathrm{H}, \mathrm{s}), 7.61$ $(2 \mathrm{H} \mathrm{m}), 7.99(1 \mathrm{H}, \mathrm{d}, \mathrm{J}=7.3 \mathrm{~Hz}) ;{ }^{13} \mathrm{C}$ NMR $\left(125 \mathrm{MHz}, \mathrm{CDCl}_{3}\right): 12.2,12.7,14.2$, 29.1, $38.4,50.3,107.7,114.1,115.5,124.1,125.2,126.2,128.4,129.9,135.2,138.3,138.4$, 140.0, 143.3, 151.7, 152.8, 169.7, 170.7, 187.5, 191.5; Anal. Calcd. for $\mathrm{C}_{48} \mathrm{H}_{46} \mathrm{~N}_{2} \mathrm{O}_{9}$ : C, 72.53; H, 5.83. Found: C, 72.61; H, 5.82.

\section{Fluorescence spectra of 3 with or without NADH or DTD}

A solution of $3(10 \mu \mathrm{M})$ in $1 \mathrm{~mL}$ of PBS containing 1 unit of DTD and $1 \mathrm{mM}$ of NADH was incubated at $37{ }^{\circ} \mathrm{C}$ for $4 \mathrm{~h}$. The fluorescence excitation-emission spectra of the solution were then recorded. The solution of 3 with 1 unit of DTD or $1 \mathrm{mM}$ of $\mathrm{NADH}$ was also incubated at $37{ }^{\circ} \mathrm{C}$ for $4 \mathrm{~h}$, and the fluorescence excitation-emission spectra of the solution were also recorded.

\section{Kinetic Parameters for reduction of 3 by DTD}

All kinetic measurements were preformed at room temperature with the excitation wavelength of $\lambda_{\mathrm{ex}}=492 \mathrm{~nm}$ and the emission wavelength of $\lambda_{\mathrm{em}}=520 \mathrm{~nm}$ in $1.0 \mathrm{~mL}$ of PBS containing 1 unit of DTD and $1 \mathrm{mM}$ of NADH. A calibration curve was measuring the fluorescence of the known concentration of rhodamine-110

刪除: nM
in the PBS. The rate of fluorescence released by DTD in the presence of $1 \mathrm{mM}$ of NADH was measured by adding a known concentration of $3(5-100 \mu \mathrm{M})$ to the reaction mixture and recording it as a function of time. The rate was calculated using the calibration curve for rhodamine-110. The enzymatic parameters were calculated by fitting the linear portion of the data (which corresponds to the unmasking of the second amino group ${ }^{1}$ ) to the Michaelis-Menten equation. The molecular weight of DTD is 31000 .

\section{Quantization of Glucose}

All the fluorimetric measurements carried out with an excitation wavelength of $\lambda_{\text {ex }}$ $\mid=492 \mathrm{~nm}$ and an emission wavelength of $\lambda_{\mathrm{em}}=520 \mathrm{~nm}$. The solutions containing 3 (5 $\mu \mathrm{M})$, DTD (1 unit), glucose dehydrogenase (1 unit), NAD $(40 \mu \mathrm{M})$, and glucose ( 0 , $1,2,3,4,5$, and $6 \mu \mathrm{M})$ in PBS with a final volume of $1 \mathrm{~mL}$ were incubated for $1 \mathrm{~h}$ at

刪除: $\mathrm{nM}$
$25{ }^{\circ} \mathrm{C}$. The fluorimetric intensity of each solution after subtracting the baseline intensity ([glucose] $=0$ ) was plotted versus the glucose concentration.

\section{References:}


1. Leytus, S. P.; Melhado, L. L.; Mangel, W. F. Biochem. J. 1983, 209, 299-307. 